\section{7. 水素水摂取が定常負荷運動時の血中乳酸値に及ぼす影響} ○吉村 咲紀 1 、市川 麻美子 ${ }^{2}$ 、清永 明 2.3 、田中 宏暁 ${ }^{2,3}$ 、 檜垣 靖樹 ${ }^{2,3}$ (福岡大学 スポーツ健康科学研究科、2福岡大 学 身体活動研究所、3福岡大学 スポーツ健康科学研究科)

【背景】水素分子は抗酸化剂として機能することが報告されて いる。水素水の持つ抗酸化作用は、疾患の治療及び予防に対す る効果のみならず、運動で生じる酸化ストレスを軽減させる 可能性がある。【目的】本研究は定常負荷運動を行った際の水 素水摂取の血中乳酸值に及ぼす効果を検証することを目的とし た。【方法】健常成人男性10名を対象に、漸増運動負荷試験よ り、各個人の血中乳酸 $2 \mathrm{mmol} / 1$ と $4 \mathrm{mmol} / 1$ 強度に相当する仕事 率を算出した。被検者は被験水を $300 \mathrm{ml}$ 摂取後、安静状態をと り、各強度で最大 1 時間の運動を行った。運動時のRPE、HR、 血中乳酸值、運動持続時間、また、運動前後で体重の測定を行っ た。運動中は15分毎に被験水を $100 \mathrm{ml}$ 飲水させた。被験水は水 素水またはプラセボ水とし、被験水と負荷強度のランダムクロ スオーバー試験にて行った。【結果】運動開始 30分までの血 中乳酸值の曲線下面積は水素水摂取の方が有意な高值を示した が $(\mathrm{p}=0.03)$ 、運動開始30分以降と運動終了後の血中乳酸值に有 意な差は認めなかった。さらに、 $2 \mathrm{mmol} / 1$ 強度の運動において、 水素水摂取の方が体重の有意な減少を認めた $(\mathrm{p}=0.04)$ 。しかし、 $4 \mathrm{mmol} / 1$ 強度の運動ではすべての項目において飲料水間に違い は認められず、運動パフォーマンスを示す運動持続時間にも差 は見られなかった $(2 \mathrm{mmol} / 1$ 強度, 水素水: 53分 29 秒, プラセ ボ水: 54 分59秒. $4 \mathrm{mmol} / 1$ 強度, 水素水: 19 分 30 秒, プラセボ水: 18分45秒)。【結論】水素水は運動初期の血中乳酸值に影響を与 えたが、長時間の持続的な効果は見られなかった。また、水素 水摂取によって体重の有意な減少が認められた。

Keywords: 水素水 血中乳酸值 定常負荷運動

\section{9. 口腔内の味覚刺激が胃内容排出に及ぼす影響}

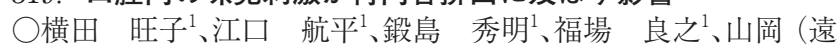
藤) 雅子 $^{1}$ ( $^{1}$ 県立広島大学)

【背景】長時間の運動では, 水分やエネルギー源の補給は欠か せないが, 補給した飲食物が胃に貯留することによって, 運動 時に胃腸障害が生じる可能性がある。そこで，運動時の胃腸 障害の予防には, 飲食物の胃内容排出（胃から十二指腸への 排出：以下GE）が素早く行われる必要がある。GEは, 口腔内 の味覚刺激によって変容する可能性があるが, どのような味覚 がGEを促進するかは明らかではない。【目的】食事の代用とし て, マルトデキストリン溶液を摂取させた後, 口腔内のみの味 覚刺激を甘味, 苦味, 酸味の 3 種類で行い, 味の違いがGE及ぼ す影響について検討した。【方法】10名の女性被験者は，早朝 空腹時に，5分間の安静後，マルトデキストリン $50 \mathrm{~g}$ 含む溶 液300g (M溶液) を一気に摂取し, その後30分間安静を保っ た。口腔内の味覚刺激はM溶液摂取後 2.5 分から, 5分毎に1分間, 合計6回行った。具体的には, 約 $15 \mathrm{ml}$ の味溶液を8秒間, 口に 含み, 吐き出す動作を5回連続的に行った。味溶液は甘味, 苦味, 酸味の3種類とし, コントロールは無味として蒸留水を用いた。 味溶液の濃度は, 味の強さが同等となるよう設定した。GEは 超音波法を用いて測定した。胃幽門部の断層像から横断面積を 算出し, 算出した胃幽門部横断面積の安静時を $0 \%$, 摂取直後 を100\%とし, 摂取後の経時的変化を胃内残留率（\%)として 求め, GEを評価した。その他に, 生理的指標として心拍数と 血圧, 主観的指標として味覚強度, 嗜好度ならびに食欲を測定 した。【結果】胃内残留率は, 無味と比較し, 甘味のみでM溶 液摂取後20分目以降に有意に減少した。味の嗜好性は甘味が最 も好む味で，苦味が最も嫌う味となった。心拍数，血圧および 食欲は，味の違いによる有意な差はなかった。【結論】口腔内 の甘味刺激のみでGEが促進した要因として, 嗜好性が関与し ている可能性が示唆された。

Keywords：味覚 胃内容排出 超音波法

\section{8. 食後のガム咀嚼が消化管の血流および食事誘発性体熱産} 生に及ぼす影響

○濱田 有香 ${ }^{1}$ 、林 直亨 ${ }^{1}$ ( $^{1}$ 東京工業大学)

【背景】食事をよく噛んで食べる（遅食い）と, 早食いよりも, 消化管の血流掞よび食後のエネルギー消費量（食事誘発性体熱 産生；DIT）が増大することを我々は報告した（Hamada et al 2014). 食後にガムを咀嚼し, 咀嚼の時間および回数を増やすと, 遅食い時の咀嚼の代替となって, 消化管の血流およびDITは増 大寸る可能性がある。【目的】食後のガム咀嚼が消化管の血流 およびDITに及ぼす影響を検討した。【方法】普通体重の健常 成人男性 12 名 (年齢 $23 \pm 1$ 歳, 身長 $175 \pm 7 \mathrm{~cm}$, 体重 $67 \pm 6 \mathrm{~kg}$ ) に, $621 \mathrm{kcal}$ の試験食（エネルギー比率：たんぱく質 $13 \%$, 脂質 $28 \%$, 炭水化物 $59 \%$ ）をできるだけ早く, または遅く摂取させた. それぞれの直後に，ガムを噛む試行では，ガム（3 kcal）を15 分間咀嚼させた。ガムを噛まない試行では, 試験食に3 kcalの 砂糖を加えた。食後3時間まで腹腔動脈および上腸間膜動脈の 血流速度と血管径を測定し, 血流量を算出した。両動脈の血流 量を合計し, 消化管の血流量とした。同時に, 酸素摂取量を測 定し, 食後3時間のDITの累計を算出した。【結果】食後3時間 の消化管の血流量の累計にはガム咀嚼の有意な効果はなかっ た。一方, 食後3時間のDITの累計はガム咀嚼によって有意に 増大した（早食い $+6 \pm 3 \mathrm{kcal}$, 遅食い $+8 \pm 3 \mathrm{kcal}, \mathrm{p}<0.05$ ). 遅食いの食後3時間のDITの累計は早食いよりも+15〜17 kcal 有意に大きく，ガム咀嚼に伴うDITの増大を上回った。【結論】 本研究では, 食後のガム咀嚼は, 消化管の血流に影響を及ぼさ なかったが, DITを増大させた。ただし，ガム咀嚼に伴うDIT の増大は, 早食いと遅食いの差を埋めるほどの大きさではなく, 遅食いの代替にはならなかった。

Keywords : ガム咀嚼 消化管の血流 食事誘発性体熱産生

\section{0. 女子大学生の立位姿勢と重心、骨格筋量、体幹筋力との} 関係

○田 めぐみ ${ }^{1}$ ( $中$ 京大学 国際教養学部)

【背景】民間会社の調査で、姿勢の悪さを自覚する若い女性が 多いことが報告されている。身体を支えるという観点で姿勢を 捉えると、体幹や下肢の筋量や筋力が影響を与えていると考え られる。

【目的】女子大学生を対象に、立位姿勢と重心（足圧分布、重 心軌跡長)、骨格筋量、体幹筋力の関係について検討すること。 【方法】女子大学生 33 名 (年齢：18.9 0 0.5歳、身長：159.0 05.3 $\mathrm{cm}$ 、体重： $50.7 \pm 5.8 \mathrm{~kg}$ ）を対象とした。立位姿勢を前方およ び右側方から撮影し、画像分析ソフトを用いてランドマークの 座標を求めた。足圧分布測定装置を用いて、30秒間静止立位時 の足圧および重心の軌跡長を測定した。生体電気インピーダン ス方式の体組成計を用いて、骨格筋量を測定した。上体起こし テストおよび背筋力の測定を実施した。

【結果】身体の左右の傾きと左右の足圧分布、重心軌跡長の間 に有意な相関関係は認められなかった $(\mathrm{r}=0.015 \sim 0.26, \mathrm{p}=$ $0.93 \sim 0.15)$ 。また、体幹・下肢筋量と重心軌跡長にも有意な 関係は認められなかった $(\mathrm{r}=-0.04 \sim 0.23, \mathrm{p}=0.83 \sim 0.22)$ 。 一方、下肢筋量が少ないと、重心が後ろ寄りになること（ $\mathrm{r}=$ 0.355, $\mathrm{p}=0.046)$ や、下肢や体幹の筋量が少ないと背中の彎曲 が大きくなること（ $\mathrm{r}=0.358 \sim 0.500, \mathrm{p}=0.041 \sim 0.003)$ が示 された。

【考察】筋量は関節トルクに関与する (Fukunaga et al. 2001) ことから、体幹や下肢の筋量が少ないと、身体の重さを支える ことが出来ないと考えられる。高齢者を対象とした研究では、 脊柱彎曲と筋力、バランス能力と筋体積が関与していることが 報告されているが、若齢者であっても、同様の傾向が見られた と考えられる。

【結論】体幹や下肢の筋量が立位姿勢や重心の位置に関与して いることが示唆された。

Keywords : 形態、体構成 筋骨格系 健康管理 
321. 女子大生を対象とした体重願望および身長願望と体力テ ストの関係 一構造分析手法を用いて-

○白川 哉子 ${ }^{1}$ 、銭谷 初穂 $^{1}$ 、小谷 恭子 $^{2}$ 、吉成 啓子 ${ }^{3}$ 、河 鰖 一彦 ${ }^{4}$ ( ${ }^{1}$ 昭和女子大学、 ${ }^{2}$ 帝塚山学院大学、 ${ }^{3}$ 白百合女子大学、 ${ }^{4}$ 関西学院大学)

【目的】我が国では瘦身が過度に強調されており女子学生など 若年層にその影響が大きいと言われている。我々は女子学生の 体力テス卜、体格指数等の相互関係に検証を加えてきた。近年 はボーデイイメージに関して調査を進めてきている。本研究 の目的は、今回得られた体力テス卜、体格指数（身長、体重、 BMI、体脂肪率)、理想体格のデー夕を用い、受講生の体重 · 身長願望（実測值－理想值）に影響を及ぼす要因を明らかにし、 体力、願望、体格指数の関係を構造的に解析することである。方 法】K学院大学における体育・スポーツ実技系科目であるスポー ツ科学演習、健康科学演習、体育方法学演習 (実技・講義融合 型）の女子受講生に文部科学省が提唱する体力テストを行い、 同時に体格指数（身長、体重、体脂肪率：BI法）を計測した。 加えて「理想体格に関するアンケート」調査を実施し、受講生 の理想体格(身長、体重)を調査した。データ収集は、2013年12 月、2015年4月の 2 回行い、359名からデータを得ることができた。 なお、共分散構造分析には、SPSS ver21、Amos ver21を用いた。 【結果・考察】本研究の被験者から得られた身長は全国平均よ り有意に大きな值であった。体重は有意差がなかった。理想身 長から実測身長を引いた身長願望は実測身長と負の相関があり $163 \mathrm{~cm}$ 近傍でY軸ゼロと交わっていた。体重願望と実測体重の 関係も負の相関があり、Y軸との交点は45kg近傍であった。体 カテスト各測定項目間の相関分析では上体起こしと他の体力テ スト項目の相関係数が低い傾向であった。また、体重願望と身 長、体重願望と体重、体重願望と身長願望の間に有意な相関関 係が認められた。更に分析を進めるため共分散構造分析を行っ た。ここでは、体脂肪率が体重願望に影響を与えている事が示 唆された。

Keywords：体重願望 身長願望 体力テスト

\section{3. 肥満者におけるサルコペニア簡易推定法の妥当性}

○古嶋 大詩 ${ }^{1} 、$ 家光 素行 ${ }^{1}$ 、浜岡 隆文 ${ }^{2}$ 、石井 好二郎 ${ }^{3} 、$ 浅原 哲子 ${ }^{4}$ 、真田 樹義 ${ }^{1}{ }^{1}$ 立命館大学、 ${ }^{2}$ 東京医科大学、 ${ }^{3}$ 同 志社大学、尓都医療センター)

【背景】近年, 簡易なサルコペニア診断法の開発が相次いでい る。 Kawakamiら (2014) は，下腿周径囲がDXA法による骨 格筋指数 (SMI) に代わるサルコペニアの指標となりうること を報告した。 また真田ら（2010）は, 年齢, BMI, 握力, ウエ スト周囲長を用いた簡易サルコペニア評価法を開発した。しか し, Kawakamiらおよび真田らの研究は健常者を対象としてお り, 肥満者においても妥当性が示されるかは不明である.【目的】 本研究の目的は, 肥満者を対象とした場合でも, 先行研究にお けるサルコペニア簡易評価法の妥当性が確認できるかを検討す ることとした.【方法】日本人成人肥満男女 47 名を対象に, 形 態計測，体組成測定および簡易体力測定を実施した。 DXA法 によって実測したSMI実測值，真田らの推定式により算出した SMI推定值は, 対応のあるt検定によって比較した. SMIのサ ルコペニアカットオフ值は, 男性 $7.77 \mathrm{~kg} / \mathrm{m}^{2}$, 女性 $6.12 \mathrm{~kg} / \mathrm{m}^{2}$ と した. また, Kawakamiらの研究に従い, 下腿周径囲を用いた サルコペニアのカットオフ值は, 男性 $34 \mathrm{~cm}$, 女性 $33 \mathrm{~cm}$ とた。 【結果】SMI推定值は, SMI実測值より有意に高い值を示した $(\mathrm{p}$ <0.01). また，SMI実測值およびSMI推定值でサルコペニアを 評価したところ, サルコペニアと診断された肥満者はSMI実測 值で9人 (19.6\%) であったが, SMI推定值では0人（0\%）であっ た。ささらに, 下腿周径囲を用いた基準では, サルコペニアと診 断された肥満者は 0 人 $(0 \%)$ であった.【結論】肥満者を対象 とした場合, 先行研究における簡易サルコペニア評価法の妥当 性は確認できなかった.

Keywords：サルコペニア 肥満 簡易評価
322. 光学3次元人体形状計測法を用いた体積測定および体脂肪 率評価の妥当性

○設楽 佳世 ${ }^{1}$ 、袴田 智子 ${ }^{1}$ 、池田 達昭 ${ }^{1}$ 平野 裕一 $^{1}$ ( ${ }^{1}$ 国 立スポーツ科学センター スポーツ科学研究部)

【背景】光学3次元人体形状計測法 (3DPS法) は, 迅速且つ簡 便に体積を測定可能な方法であり，体脂肪率の簡易評価法とし ての応用が期待される。【目的】本研究は，体積および体脂肪 率の代表的な評価方法である水中体重秤量法（UWW法）およ び空気置換法（ADP法）との比較から，3DPS法による体積測 定および体脂肪率評価の妥当性について検討することを目的 とした。【方法】一般成人男性53名を対象に, UWW法, ADP 法および3DPS法による体積測定を行い, 得られた体積值から 体脂肪率を算出した (Brozek et al., 1963). 3DPS法により測 定した体積は, 機能的残気量の推定值 (Crapo et al., 1982) で 補正した。【結果】UWW法と3DPS法掞よびADP法により測定 した体積との間には，それぞれ強い正の相関関係が認められ た（いずれも $\mathrm{r} \geqq 0.99 ）$. UWW法を基準として, 3DPS法および ADP法による体脂肪率の推定值の標準誤差を求めると， $3.5 \%$ および1.7\%であった。 3DPS法による体脂肪率の推定誤差が大 きい被験者を対象に，セグメント別の体積比を算出すると，髪 の毛を含む頭部の体積比や, 脇や股下などレーザー照射範囲の 制限を受けやすい部位を含む四肢の体積比が，平均值士標準偏 差の範囲外に分布する傾向がみられた。また，ADP法による 肺容量の測定值を用いて3DPSで測定した体積を補正し体脂肪 率を推定したところ，UWW法および3DPS法による体脂肪率

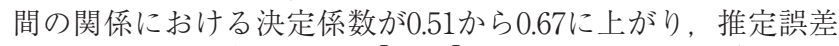
のばらつきが抑えられた。【結論】以上の結果より，1）3DPS 法により体積の個人差を捉えることができること, 2) 3DPS法 による体脂肪率の推定精度が, ADP法と比較して低いこと，3） 3DPS法を体脂肪率の評価方法として応用するためには, 頭部 体積の測定精度および四肢体積の分析精度の向上と, 機能的残 気量の補正方法の検討が必要であること，が示された。

Keywords : 光学3次元人体形状計測法 体積 体脂肪率

\section{4. レスリング全日本選手権出場選手の減量実施状況}

$\bigcirc$ 元永 恵子 ${ }^{1}$ 、荒川 裕志 ${ }^{2,3}$ 、有光 环磨、山下 ${ }^{1}$ 大地 ${ }^{1} 、$ 藤山 光太朗 ${ }^{3}$ 、松永 共広 ${ }^{3}$ 、栄 和人 5 、西口 茂樹 4,6 、和 田 貴広 ${ }^{4,7}$ 、中嶋 耕平 ${ }^{1,3}\left({ }^{1} \mathrm{JISS} 、{ }^{2}\right.$ 国武大、 ${ }^{3}$ 日本レスリング協会、 ${ }^{4} \mathrm{JOC} 、{ }^{5}$ 至大、 ${ }^{6}$ 拓大、 ${ }^{7}$ 国士大)

【目的】日本トップレベルのレスリング選手の計量に向けた急 速減量に伴う体重変化とコンディションを確認し、コンディ ション調整のための資料を得ることとした。【方法】2014年度 全日本選手権大会に出場した347名のうち本調査に同意の得ら れた選手（有効回答156名）を対象とし、質問紙を用いて計量1 か月前から試合当日朝までの体重を小数点第 1 位まで記入させ た。出場階級より上回っている体重を「体重超過量」、これを 出場階級で標準化したものを「体重超過率（\%)」とした。併 せてコンデイションチェックを計量前日と当日朝に実施した。 【結果】1か月前では8割以上の選手が体重超過しており、計量 当日朝でも $48.7 \%$ が超過していた。試合当日朝は 8 割以上の選 手が計量体重より重かった。男子は1週間前で4kg以上体重が 超過している階級が多く、軽量級では体重超過率も大きかった。 女子は体重超過量、超過率ともに男子よりも小さかった。試合 当日朝の体重は、全てのスタイル・階級で1週間前の体重まで には回復していなかった。コンデイションでは減量実施群で、 計量時と比べて試合当日朝の方が改善していた。特に計量時は 空腹感や口渴感が強いことが確認できた。安心感で計量時と試 合当日朝であまり差が見られなかったが、これは試合当日朝も 競技に向けた不安感があるためと推測される。【結論】今回の 調査では減量実施者のみで体重の変化を追ったことから、トッ プ選手の多くが厳しい体重調整を行っていることをこれまでの 報告よりも明確に示すことができた。またコンディションでは 安心感以外の項目で試合当日に改善することも確認できた。今 後は減量幅や計量後の体重増加率とコンディションとの関連に ついて検討したい。

Keywords：レスリング 体重 減量 


\section{5。下腿の形態が運動能力に及ぼす影響}

$\bigcirc$ 神田 明典 ${ }^{1}$ 、山本 真孝 ${ }^{1}$ 、楠本 一樹 ${ }^{1}$ 、枝松 千尋 ${ }^{2}$ 、飯 田 智行 ${ }^{3}$ 、吉田 悦男 ${ }^{1}$ ( ${ }^{1}$ 倉敷芸術科学大学大学院、倉敷芸 術科学大学、3就実大学)

【背景】一般的に、足首が細くアキレス腱の長いスラリとした 脚は運動能力が高いことを予想させる。近年、運動中の腱の振 る舞いが爆発的で効率的なパワー発揮において重要な役割を果 たしていることが明らかとなりつつある。さらにアキレス腱の 存在によって足首を細くすることが可能となり、慣性モーメン トの小さい形態をつくることができると考えられる。【目的】 本研究は、下腿の形態が運動能力に及ぼす影響について検討す る。【方法】被験者は、スポーツ経験のある男子大学生33名と した。メジャーとマルチン式身体計測器を用いて脚の形態測 定、超音波診断装置を用いて下腿部の筋厚とアキレス腱厚の測 定を行なった。さらに、急速解放法による下腿の膝関節周りの 慣性モーメントを計測し回転半径を算出した。運動能力を評価 するため、50m走の測定と最大ホッピングを用いてRDJindex を算出した。【結果】50m走タイムとの相関では、下腿の膝関 節周りの回転半径と足首周囲径に相関関係が観察された。つま り、足首周囲径が細いと回転半径が小さくなり、脚を振り回 しやすくなったため、50m走タイムがあがったと考えられた。 RDJindexとの相関では、アキレス腱長は無相関であった。【結 論】足首周囲径が細ければ運動能力が高まることが明らかと なった。一方、アキレス腱長は運動能力に影響を与えなかった。 Keywords：アキレス腱 慣性モーメント 運動能力

327. 地域高齢者における運動教室前の心理得点の性差について $\bigcirc$ 大川 昌宏 ${ }^{1}$ 井手 裕子 ${ }^{2}$ 、櫻井 忠義 ${ }^{3}$ ( ${ }^{1}$ 国際武道大学大 学院 武道・スポーツ研究科、 ${ }^{2}$ 九州看護福祉大学 鍼尒スポー 学科、 ${ }^{3}$ 日本体育大学大学院 体育科学研究科)

【背景】：骨格筋が萎縮してしまう老年症候群（サルコペニア） あるいはフレイル対策として様々な健康運動教室などが開催さ れ、運動の効果について検討されている。しかし、これまでに 報告されている論文では対象者の人数や性差について検討した 評価が行われていない。【目的】：健康運動教室実施前における 心理面の現状について明らかにすることおよびサンプルサイ ズについて検討することとした。【方法】：60歳から83歳の中・ 高齢者32名（男性：15名、女性17名）とした。心理指標には 日本語短縮版気分プロフィール調査（Profile of Mood States: POMS）を用いた。解析には対応のない検定を用いた。6尺度 を用いた重回帰分析を行った。有意水準は $\alpha=.05$ および $\beta=.20$ とし、効果量を用いて評価を行った。【結果】：POMSの6つの 因子のうち、怒り一敵意」尺度得点については女性に比べて 1.2 倍得点が高かった（ $\mathrm{d}=1.38[.59,2.17] 、 \mathrm{p}<.001$ 、検定力 $=.97)$ 。 「活気」を除く4尺度については男性の得点が高かった（g=.36 から.69）。また、「怒り一敵意」尺度を従属変数とし、他の5尺 度を説明変数とした重回帰分析を行った結果、「怒り一敵意」 尺度得点は「疲労」尺度得点による影響があることが示唆され た（調整済み $\mathrm{R}^{2}$ 值：.293、 $\mathrm{p}=.022$ 、推定值の標準誤差 : 5.754）。 しかし、女性にはこれらのような傾向を示さなかった。【結論】 男性の場合に「怒り一敵意」尺度が高得点を示した理由とし て、1週間前の「疲労」の蓄積があったことが推察され、これ を除くことが必要だと考えられる。また、男女各40名ほどを対 象とすることによって「抑うつ一落込み」および「疲労」の男 女差については効果量中程度以上の差がみられることが推察さ れた。

Keywords : 高齢者 性差 サルコペニア
326. 半腱様筋の筋束長及び腱組織の形態特徵について ○松 敏彦 ${ }^{1}$ 、船渡 和男 ${ }^{2}\left({ }^{1}\right.$ 大阪大学 全学教育推進機構、 ${ }^{2}$ 日本体育大学 体育学部)

【背景】ハムストリングスを構成する半腱様筋は、股関節と膝 関節の二関節筋として多様な動きに対応すべく、大腿二頭筋、 半膜様筋と共に機能的、合目的的な形態を呈しているといえ る。それは筋束と腱組織がどのような配列と付着様相であるの か、隣接筋との関わりはどうであろうか。【目的】肉眼解剖学 的手法を用いて半腱様筋の形態的特徵を捉えることである。【方 法】日本人男性献体 7 体 (大阪大学医学部解剖学講座協力、医 学倫理審査委員会承認) を対象に半腱様筋を摘出し、筋組織の 全てを筋束レベルに分離した。同時に起始・停止腱膜、腱画と の筋束付着様相を観察し、デジタルノギスにて筋束長を計測し た。【結果・考察】半腱様笳は、大腿二頭筋長頭との癒合した 協同腱膜によって坐骨結節から起始し、その筋束起始は長頭腱 膜に依存的であった。停止腱膜長は起始腱膜長の $1.8 \sim 3.1$ 倍で あった。筋束長は被験体間で近位筋束が71.0 105.6mm、遠 位筋束長が81.3〜 104.9mmであり、近位及び遠位筋束長の平 均值の差に有意性 $(\mathrm{P}<0.001)$ が認められた。被験体間で「近 位筋束長 $>$ 遠位筋束長」を示したのが 3 体、「近位筋束長 $<$ 遠 位筋束長」が 4 体であった。左右肢比較では 2 体の遠位筋束長 を除いて有意差が認められた。筋束長/筋腱複合体長では、近 位筋束が14.8～22.4\%、遠位筋束が17.0～24.0\%であった。また、 4 体 7 側に腱画を介さず起始と停止腱膜間を直接走向する一貫 した筋束や腱組織の結合による近位・遠位を連続する筋束が存 在した。これらは変異に類し、筋腹深部に位置していた。腱画 は筋腹の後方上部から前方下部にかけて斜面状に位置する腱膜 で、大きさは長径100〜106mmであった。本研究から近位と 遠位及び左右の筋束長の関係は一様でなく、筋束長／筋腱複合 体長も個人差が明らかとなり、この要因として近・遠位腱膜の 形状 (発達度) と部位差との関係が重要な鍵になるものと推察 する。

Keywords : 半腱様筋 肉眼解剖学 筋束長

\section{8. 日本人における出生時体重と筋力との関係}

$\bigcirc$ 青山友子 1 、宮武 伸行 ${ }^{2}$ 、發坂 耕治 ${ }^{3}$ 、関 明穂 ${ }^{3}$ 、田 畑 泉 ${ }^{4}$ 、樋口 満 ${ }^{5}$ 宮地 元彦 1 、田中 茂穂 ${ }^{1}$ ( $^{1}$ 医薬健栄 研 国立健康 - 栄養研究所、 ${ }^{2}$ 香川大学、 ${ }^{3}$ 岡山県南部健康づく りセンター、 ${ }^{4}$ 立命館大学、 ${ }^{5}$ 早稲田大学)

【背景】出生時体重が軽いと将来的に握力を指標とした筋力が 低いことが、欧米を中心とした複数の国において報告されてい る。しかし、欧米人と比べて出生時体重が軽い日本人における 出生時体重と握力との関係や、その関係に及ぼす身体活動量の 影響は不明である。【目的】日本人における出生時体重と握力 との関係を、身体活動量の影響を考慮して検討する。【方法】 我が国において母子手帳の活用が始まった1949年以降に、単胎 かつ $1.5 \mathrm{~kg}$ 以上で出生した30歳以上の日本人を対象とした。質 問紙調査により、母子（健康）手帳の記録または母親の記憶に 基づいた出生時体重の回答が得られた男性 137 人、女性 230 人を 解析対象とした。握力は左右 2 回ずつ測定し、それぞれの高い 方の值を平均した。三次元加速度計（アクティマーカー、パナ ソニック）を用いて日常生活における身体活動量を7日間にわ

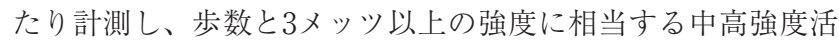
動時間を解析に用いた。【結果】握力は女性においてのみ、出 生時体重 $(r=0.21)$ 、歩数 $(r=0.16)$ 、中高強度活動時間 $(r=0.13)$ と有意な正の相関関係が認められた。出生時体重の握力に対す る寄与は、重回帰分析において年齢と体重で調整しても有意で あり $(\beta=0.17) 、 さ ら に$ 身体活動量で調整しても寄与の大き さ $(\beta)$ はほとんど変わらなかった（歩数： $\beta=0.18$ 、中高強 度活動時間： $\beta=0.16)$ 。男性においては年齢や体重、身体活 動量の調整の有無に関わらず出生時体重と握力との関係は認め られなかった。【結論】日本人成人における出生時体重と握力 との関係は性別によって異なり、女性では出生時体重が軽いと 握力が低いこと、その関係は歩数や中高強度活動時間の影響を ほとんど受けないことが示唆された。

Keywords : 出生時体重 筋力 身体活動量 